Article

\title{
Pre-Caecal Disappearance of Starch and Volatile Fatty Acid (VFA) Content in Digesta of Caecum of Growing Pigs Fed with Ripe Hulled Shredded Acorns in Their Diet
}

\author{
Maria Grazia Cappai ${ }^{1, *(\mathbb{D}}$, Petra Wolf ${ }^{2,3}{ }^{\mathbb{C}}$, Walter Pinna ${ }^{1}$, Peter Rust ${ }^{2}$ and Josef Kamphues ${ }^{2}$ \\ 1 Department of Veterinary Medicine, Università di Sassari, Via Vienna 2, 07100 Sassari, Italy; \\ prodanim@uniss.it \\ 2 Institute of Animal Nutrition, University of Veterinary Medicine Hannover, Foundation, \\ Bischofsholer Damm 15, 30163 Hannover, Germany; Petra.Wolf@uni-rostock.de (P.W.); \\ rustpet@aol.com (P.R.); Josef.Kamphues@tiho-hannover.de (J.K.) \\ 3 Institute of Nutrition Physiology and Animal Nutrition, University of Rostock, Justus-von-Liebig-Weg 6b, \\ 18059 Rostock, Germany \\ * Correspondence: mgcappai@uniss.it; Tel.: +39-079-229444
}

Received: 20 September 2020; Accepted: 25 October 2020; Published: 29 October 2020

\begin{abstract}
Physical properties and chemical composition of caecum chyme, with particular regard to starch pre-caecal disappearance and volatile fatty acid (VFA, C2-C5) content, were determined in 16 growing pigs fed raw acorns in the diet. Pigs were singly housed and divided into two experimental feeding groups (each $n=8$ ). The control group was fed a conventional complete diet for pigs (pelleted; $890 \mathrm{~g}$ dry matter (DM)/kg, $435 \mathrm{~g}$ starch/kg DM, based on cereals and soybean extraction meal). The acorn-fed group was offered a combined diet, 70\% of ripe whole shredded acorns $(695 \mathrm{~g} \mathrm{DM} / \mathrm{kg}$, $447 \mathrm{~g}$ starch/kg DM) and 30\% of the control diet. After one week, all 16 animals were slaughtered, and contents of the caudal ileum and caecum were analyzed for dry matter, crude ash, and starch. Fresh caecum chyme was analyzed for VFA content and molar proportion of acetic, propionic, n-butyric, $\mathrm{n}$-valeric acid were determined. VFA per $\mathrm{kg}$ of organic matter (OM) in the caecum differed significantly between groups $(p=0.047)$. Pre-caecal disappearance ( $\mathrm{pCD}$ ) of acorn native starch turned out to be high (>95\%). Estimated VFA content in caecum in the acorn combined diet resulted in $8.72 \mathrm{~g}$ per $\mathrm{kg}$ of $\mathrm{OM}$, and the relationship based on molar proportion between acetic:propionic:n-butyric:n-valeric acid was 1:0.2:0.1:0.04, which pointed to higher proportions of n-valeric acid when hulled shredded acorns are fed to pigs.
\end{abstract}

Keywords: acorns; butyric acid; dietetic; fermentation; pig; valeric acid

\section{Introduction}

Public awareness about the appropriateness of livestock feeding practices has sharply increased in recent decades. Consumers' interest regarding animal farming conditions and feeding management of small-scale animal productions has led to a progressive increase in demand for products from traditional and slower growth-rate systems. In different countries of the Mediterranean area, extensive farming of livestock can rely on the seasonal availability of natural feeding sources as main part of animal diet.

In traditional pork production, the finishing diet of pigs employs acorns as the main ingredient of the diet [1-11]. Acorns are indehiscent fruits (achaenia) of the oak tree (Genus Quercus), with one seed enveloped in a wooden pericarp [12]. Throughout fall and winter, acorns are freely available on the 
ground of oak forests where grazing livestock and wild fauna can consume the fruits. Acorns represent a valuable energy source, especially for animals tolerant to feedstuffs rich in hydrolysable tannins $[13,14]$. Due to the high starch and crude fat content, acorns can be considered an energy-dense feedstuff and a valuable source of antioxidant compounds, being also rich in polyunsaturated fatty acids (PUFA), polyphenols, and moderately high amounts of $\mathrm{Zn}, \mathrm{Cu}$, and Se [15]. Previous trials compared the metabolizable energy content of acorns to that of beet pulp or to diets containing $70 \%$ of wheat or $75 \%$ of barley, determined from apparent total tract digestibility of crude nutrients $[15,16]$. As a result of energy density and biologically active compounds, pigs traditionally raised for cured ham production can benefit from the nutritional properties of raw acorns during the fattening period [17-20].

The consumption of acorns by pigs needs to be explored in relation to pre-caecal disappearance (pCD) of starch and potential fermentation in the hindgut, which may vary according to the botanical origin of the acorn. The apparent total tract digestibility of acorn starch can strictly depend on the starch granule ultra-microscopic characteristics [16], which differ across the genus Quercus [21,22]. Amylose to amylopectin ratio can have an impact on the efficiency of enzymatic digestion by salivary and pancreatic $\alpha$-amylase in pigs, potentially giving rise to different extents of pre-cecal digestibility rates of acorn starch. In fact, a certain amount of starch escaping enzymatic digestion in the small intestine enters the hindgut, where bacterial fermentations take place and results in the production of different extents of volatile fatty acids (VFA). Acetic, propionic, and butyric acid, followed by valeric and iso-valeric acids, are products of proteolitic and saccharolytic fermentations by microbes. Any starch resistant to enzymatic digestion could be fermented by intestinal bacteria in the hindgut. In 2015, Mößeler et al. [23] report how starch amounts being digested and absorbed in the small intestine is of special interest due to the impact on post-ileal degradation of resistant starch by intestinal microflora. Beneficial effects on colonic health are in fact reported due to butyric acid production. However, in spite of the well-known biologic effects of gut-derived VFA for the host, the literature contains only a few papers on PCD of starch in the case of acorn-based diets fed to pigs [21,22]. Therefore, the objective of this study was to explore the extent of $\mathrm{pCD}$ of starch, starch content in digesta of caecum and VFA concentration and molar proportions in growing pigs fed raw hulled shredded acorns (Downy oak, Quercus pubescens Willd.) in the diet.

\section{Materials and Methods}

\subsection{Animals and Diets}

Animal handling complied with the recommendations of European Union Directive 2010/63/EU [24] concerning animal care. The project was approved by the Ethics Committee on Animal Welfare of the Hannover District Government in accordance with German legislation on animal welfare.

The number of animals included in the trials was reduced to the minimum adequate number of animals to refine the reliable results, according to the tree Rs principle for experimental animal care. All procedures reported in this trial belong to conventional clinical and breeding practices; in particular, feeding, body weight record, and slaughter procedure were carried out in accordance with current European legislation on animal protection.

A total of 16 cross-bred (Duroc sires on Large White X German Landrace) growing pigs were enrolled in an experimental feeding trial (16 pigs $=8 \mathrm{vs}$. 8); the 16 pigs were allotted to two experimental groups (control, n. 8 vs. acorn-fed, n. 8 pigs, all individually housed, where each pig represented an independent animal experimental unit). The eight pigs of both groups were individually housed in litterless stalls and allotted to the different dietary treatments, according to a matched pairs approach (based on the body weight of pigs at start; sex ratio differed between experimental groups because animals were segregated according to body weight; age of pigs does not represent a fixed factor at this stage). The feeding plan consisted of two distinct phases (as adopted in earlier studies [15]) planned as follows: phase 1, representing the adaptation period (eight days, all 16 pigs were fed with a pelleted 
complete diet for growers); phase 2, n. 8 pigs out of 16 were switched to the experimental diet for eight days, based on ripe hulled shredded acorns. This experimental diet was formulated to test the effect of one single ingredient (acorn). In the experimental combined diet, the investigated ingredient was combined a reference complete feed. The pelleted diet administered during the phase 1 , based on cereals and soybean meal (Table 1), was combined with a proportion of $70 \%$ of raw hulled shredded acorns, as fed, in the form of a mixed meal diet. Two nutritional specifics were fulfilled with such acorn proportion: (a) the achievement of comparable contents of starch and OM in the DM of the two diets; (b) acorns as the major source of those nutrients in the combined diet. Thus, this proportion $(70 \%: 30 \%$ = raw acorns:pelleted complete feed, as fed) was calculated for experimental needs and not to meet productive yields. The diet also provided large amounts of polyphenols, from which those with protein precipitating activities were determined and expressed as tannic acid equivalent, as detailed further.

Table 1. Analyzed nutrient composition of the two experimental diets.

\begin{tabular}{ccc}
\hline Ingredients (g/kg Diet, as Fed) & Control Diet & Acorn Combined Diet \\
\hline Hulled shredded acorns & 0 & 700 \\
Wheat & 400 & 120 \\
Barley & 340 & 102 \\
Soybean meal & 200 & 60 \\
Soy oil & 11 & 3 \\
Mineral premix & 22 & 66 \\
Lysine/Methionine & 7 & \\
Analyzed chemical composition & & 695 \\
Dry matter (g/kg, as fed) & 890 & 586 \\
Ash (g/kg DM) & 684 & 113 \\
Crude protein (g/kg DM) & 175 & 112 \\
Crude fibre (g/kg DM) & 45.0 & 45.9 \\
Crude fat (g/kg DM) & 22.8 & 447 \\
Starch (g/kg DM) & 435 & 941 \\
OM (g/kg DM) & 931 & 36.1 \\
TAE (g/kg DM) & n. d. &
\end{tabular}

The rest of the pigs (n. 8) continued to be fed with the pelleted complete diet and were considered as the control group (phase 2, lasting eight days).

Ingredients and chemical composition of the two experimental diets is reported in Table 1. Pigs of both groups (initial body weight BW: 14.2 to $27.6 \mathrm{~kg}$, age: 7-9 weeks old) were fed ad libitum and had free access to water. Daily feed consumption $\left(\mathrm{gd}^{-1}\right)$ was recorded per each pig in both experimental groups throughout the trial. The diet was offered fresh every morning and DM content of leftovers was determined daily for every pig. Feed intake was recorded on the last day of the feeding trial, when all animals were euthanized $8 \mathrm{~h}$ after being given free access to feed, to allow last meal nutrients to reach the caecum.

\subsection{Sampling at Necropsy}

The euthanizing protocol consisted of a preliminary deep sedation of each pig (intramuscular single injection of Stresnil 40\%, corresponding to $2 \mathrm{mg}$ azaperon $/ \mathrm{kg} \mathrm{BW}$ ). The intracardiac injection was carried out after $20-25$ min from sedation by means of an euthanasic (Tanax ${ }^{\circledR} 1 \mathrm{~mL} / 10 \mathrm{~kg} \mathrm{BW}$ ). On each unconscious animal laying on the right side, the needle was inserted between the 3rd and 4th left ribs at heart level.

The different tracts of the gut were immediately separated with double ties to prevent luminal content from mixing. Subsequently, all tracts were removed carefully from the carcass. Luminal contents of the caudal small intestine were isolated following the proportion described by Willing and van Kessel [25] and sampled, weighed, and immediately assessed for the $\mathrm{pH}$ value of digesta. Also, caecum content was sampled, weighed, and assessed for $\mathrm{pH}$ value. For this purpose, $1.0 \mathrm{~g}$ of chyme 
was diluted in a tube containing $5 \mathrm{~mL}$ of distilled water. The probe of a handy $\mathrm{pH}$-meter recorded values at a conventional temperature of $25^{\circ} \mathrm{C}$. One aliquot of both ileum and caecum chyme was processed fresh for the determination of VFA contents.

\subsection{Chemical Analyses}

Feed and chyme samples from ileum, caecum, and colon were weighed and vacuum packed frozen immediately after collection, then freeze-dried (freeze dryer: alpha 1-4 LSC, Martin Christ, Gefriertrocknungsanlagen $\mathrm{GmbH}$, Osterode am Harz, Germany), and analyzed in duplicate for dry matter, ashes, and starch, as described by Naumann and Bassler (2012) [26]. Starch content was determined with the polarimetric method (1999/79/CE) [27], basing calculations on a gyration radius of $184^{\circ}$, used for "other starches."

The natural tannins, showing a protein precipitating activity at polyvinyl-pyrrolidone adsorption, were estimated by the Folin-Ciocalteau method [28], modified by Waterman and Mole [29]. Spectrograms were used to calculate the content of polyphenols with protein precipitating activity from total polyphenol content, expressed as Tannic Acid Equivalents (TAE).

The content of volatile fatty acids in the homogenized fresh chyme was determined by gas chromatography. The samples were first mixed with an internal standard (batch: $10 \mathrm{~mL} 89 \%$ formic acid and $0.1 \mathrm{~mL}$ 4-methylvaleric acid), centrifuged and introduced in the gas chromatograph (610 Series, Unicam, Kassel, Germany) at a column temperature of $155^{\circ} \mathrm{C}$ (injector: $175^{\circ} \mathrm{C}$, detector: $180^{\circ} \mathrm{C}$ ). After separation of the fatty acids along the $2 \mathrm{~m}$ long packed column within a 25-min analysis time, the determination by means of flame ionization detector in the following order: acetic acid, propionic acid, iso-butyric acid, n-butyric acid, iso-valeric acid, and n-valeric acid. Total VFA and molar proportion of acetic, propionic, n-butyric, iso-butyric, valeric, and iso-valeric acids were calculated on respective molar weight [30].

\subsection{Calculations and Statistics}

In order to estimate the $p C D$ of starch, the following calculations were used:

$$
p C D x=\left(\frac{x i-x c}{x i}\right) \times 100
$$

where $x$ is the variable (starch $\mathrm{g} / \mathrm{kg}$ DM of diet), $x i$ stands for individual intake calculated from the difference between the amount of feed offered and the left over weighed from the feeder of the last meal (on DM basis); $x c$ stands for starch content in the whole chyme (on DM basis) entering the caecum $8 \mathrm{~h}$ after the last meal [15]. For this purpose, in fact, the content of the caecum was weighed immediately after dissection.

Student's $t$-test was used to compare means of parameters obtained in the two experimental groups fed with different diets. Selected parameters were analyzed for correlation with Pearson test. Statistical analysis was carried out by means of Minitab_18 ( ${ }^{(} 2020$ Minitab, LLC, State College, PA, USA). All statements of statistical significance are based upon $p<0.05$.

\section{Results}

The physico-chemical parameters of chyme obtained from ileum, caecum, and colon are reported in Table 2. The $\mathrm{pH}$ values of chyme from ileum and caecum did not differ comparing animals fed the two experimental diets, being, however, higher in caecum chyme of the acorn-fed pigs (Figure 1). 
Table 2. Analyzed parameters in digesta from ileum and caecum of pigs fed the two experimental diets. Values reported as mean and pooled standard error with respective significance.

\begin{tabular}{|c|c|c|c|c|}
\hline Diet & CD & $\mathrm{ABD}$ & & \\
\hline Animals & 8 & 8 & SE & $p$-value \\
\hline \multicolumn{5}{|l|}{ Parameters of digesta of caudal ileum } \\
\hline $\mathrm{pH}$ & 6.33 & 6.54 & 0.51 & 0.638 \\
\hline $\mathrm{DM} g / \mathrm{kg}$ & 153 & 143 & 87.1 & 0.245 \\
\hline Starch $\mathrm{g} / \mathrm{kg} \mathrm{DM}$ & 136 & 131 & 21.1 & 0.749 \\
\hline \multicolumn{5}{|l|}{ Parameters of digesta of caecum } \\
\hline $\mathrm{pH}$ & 5.65 & 5.97 & 0.13 & 0.134 \\
\hline $\mathrm{DM} g / \mathrm{kg}$ & 149.5 & 264 & 85 & 0.107 \\
\hline Starch $\mathrm{g} / \mathrm{kg} \mathrm{DM}$ & 103 & 154 & 19.4 & 0.010 \\
\hline VFA $(\mathrm{g} / \mathrm{kg} \mathrm{OM})$ & 8.17 & 5.92 & 0.50 & 0.047 \\
\hline acetic acid (g/molar weight) & 0.070 & 0.059 & 0.006 & 0.165 \\
\hline propionic acid ( $\mathrm{g} /$ molar weight) & 0.037 & 0.018 & 0.005 & 0.075 \\
\hline n-butyric acid (g/molar weight) & 0.018 & 0.009 & 0.006 & 0.277 \\
\hline $\mathrm{n}$-valeric acid (g/molar weight) & 0.001 & 0.002 & 0.001 & 0.359 \\
\hline
\end{tabular}

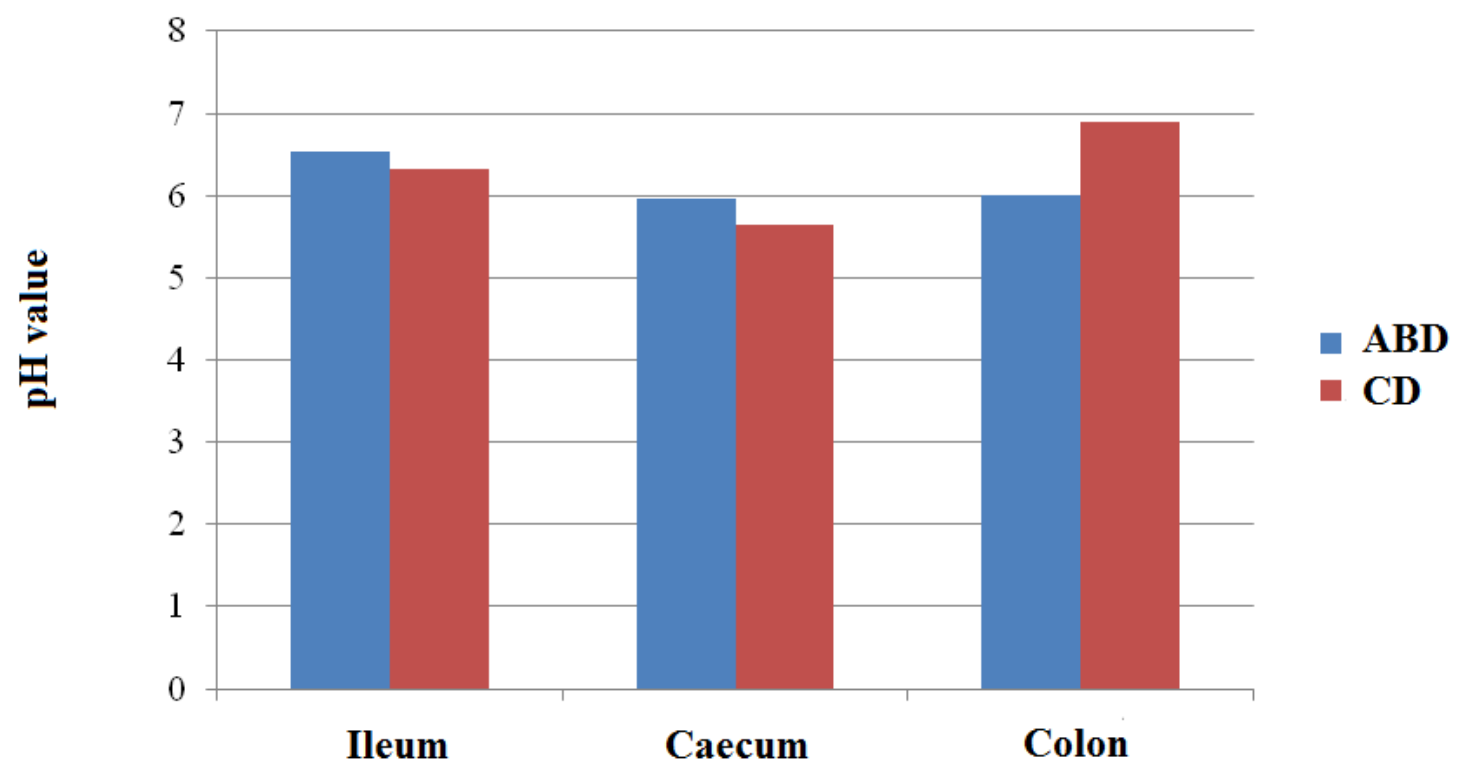

Figure 1. Histogram displaying average $\mathrm{pH}$ values in chyme from different intestinal tracts (ileum, caecum and colon) of pigs of the two experimental groups (acorn-based diet (ABD) vs. control diet (CD)).

Pre-caecal disappearance of starch is reported in Table 3. VFA determined in caecum chyme of pigs displayed significant variations $(p=0.047)$ between the two groups, being higher in pigs fed with the control diet (CD). Furthermore, $\mathrm{pH}$ values of caecum chyme were significantly $(p=0.023)$ and strongly negatively correlated $(\varrho=-0.977)$ with VFA concentrations (Table 4$)$. Relationship among molar proportions of acetic: propionic: butyric: n-valeric acids in caecum chyme of pigs from the control (CD) and the acorn-based diet (ABD) was 1:0.5:0.3:0.01 and 1:0.3:0.2:0.03, respectively. Calculated relationship of respective VFA from potential feeding of pure raw shredded hulled acorns in caecum chyme turned out to be 1:0.2:0.1:0.04. Such calculations highlighted higher proportions of n-valeric acid. The calculated pCD of starch from acorns turned out to rate at $99.5 \%$ (Table 3). 
Table 3. Daily intakes and pre-caecal disappearance ( $\mathrm{pCD}$ ) of starch in digesta of pigs fed the two experimental diets. Values are expressed as mean and pooled standard error with respective $p$-value.

\begin{tabular}{ccccc}
\hline Diet & CD & ABD & & \\
\hline Animals & 8 & 8 & & \\
& & & SE & $p$-value \\
Feed intake (g as fed/kg BW/8 h) & 46.1 & 36.9 & & \\
DM intake (g/kg BW/8 h) & 41.0 & 25.7 & 23.4 & 0.631 \\
pCD of Starch (\%) & 99.7 & 99.5 & 20.1 & 0.365 \\
\hline
\end{tabular}

Table 4. Correlation coefficients of Pearson and respective statistical significance ( $p$-value, italics; bold $p$-value $<0.05$ ) between the total content of VFA, acetic acid, propionic, n-butyrric, n-valeric acid, and $\mathrm{pH}$ value of chyme in the caecum of pigs fed with the two experimental diets.

\begin{tabular}{cccccc}
\hline & VFA & Acetic a. & Propionic a. & n-Butyrric a. & n-Valeric a. \\
\hline Acetic a. & 0.873 & & & & \\
\hline & 0.127 & & & & \\
\hline Propionic a. & 0.953 & 0.687 & & & \\
\hline & $\mathbf{0 . 0 4 7}$ & 0.313 & & & \\
\hline n-butyrric a. & 0.792 & 0.406 & 0.919 & & \\
\hline & 0.208 & 0.594 & 0.081 & & \\
\hline n-valeric a. & -0.379 & -0.366 & -0.395 & -0.101 & \\
\hline & 0.621 & 0.634 & 0.605 & 0.899 & 0.173 \\
\hline pH & -0.977 & -0.843 & -0.924 & -0.822 & 0.827 \\
\hline & $\mathbf{0 . 0 2 3}$ & 0.157 & 0.076 & 0.178 & \\
\hline
\end{tabular}

\section{Discussion}

The present investigation was undertaken with the purpose to determine the effect of whole hulled acorn fed to growing pigs on caecum chyme characteristics. The caecum represents the anatomical district that sets the passage between fore- and hindgut as well as the different digestion of nutrients. The experimental diets were formulated to reach comparable starch contents, but necessarily differed in physical form and other nutrient contents. Different DM, crude protein and crude fiber content in the acorn diet should be taken into account in this case. Moreover, acorns are well known to provide considerable amounts of polyphenols, in particular of hydrolysable tannins. In fact, the ABD provided $36.1 \mathrm{~g}$ of tannic acid equivalent (TAE) per $\mathrm{kg}$ DM of diet.

The dietetic importance of native starch fractions undergoing enzymatic digestion by the host and fermentation by hindgut microflora are expressed mainly in the production of VFA, to which several functional properties are acknowledged. Beyond the nutritional value in terms of energy content of acorns as starchy feeding stuffs, the fate of starch along the gastro-intestinal tracts of the pig was not explored exhaustively to date except for investigations reporting results on the use of acorns of different botanical origin in the diet of pigs [21,22].

The recent beneficial effects from starch fermentation in the hindgut [31-34] pointed to the role of resistant starch as a prebiotic compound, metabolized by bacterial populations in anaerobic environment, leading to VFA production. Starches of different botanical origin can undergo different extents of microbial fermentations and therefore give rise to different amounts and proportions of VFA. The results of this investigation contribute to the advancement of the knowledge about the amount of starch when hulled acorns are combined in the diet entering the caecum (animals were slaughtered $8 \mathrm{~h}$ after last meal administration, the average time needed for the meal to get into the caecum in the pig), pCD, and VFA content. The two experimental diets produced differences in the digesta composition from ileum and caecum. In particular, the DM content of digesta of caecum turned out to be higher in the 
ABD pigs if compared to pigs fed with the control diet, though in a non-significant way. Starch amount in the ileum did not differ in the two groups of pigs, whereas it did as to caecum chyme. In fact, starch content in DM of caecum digesta was comparatively higher in ABD pigs in a significant way. However, VFA content on OM basis of caecum chyme differed significantly, being higher in pigs fed with the control diet. This finding can be attributed to different factors having an effect on fermentation of starch in the caecum. Both the physical form and the amount of crude fiber of the diet can determine different transit time of digesta across the different gastrointestinal tracts. The passage rate of nutrients is enforced in the hindgut in case of coarse grinding of ingredients and high crude fiber content in the diet of pigs. Such factors may contribute to the differences observed, both as to starch content in DM of digesta and VFA content per $\mathrm{kg} \mathrm{OM}$ in the chyme of caecum of pigs from the two groups. This finding is probably influenced by the presence of hulls from shredded acorns, that could be detected non-degraded up to the feces, as reported in previous trials [16]. Cherbut et al. [35] pointed to the effect of short chain fatty acids SCFA on gastric emptying and ileum motility by fermentations of microflora in the hindgut, thus showing the effect also on upper tracts of the gut and not only locally. Further, polyphenols contained in raw acorns $[4,14]$ can also affect the microbial population in the hindgut and are responsible for VFA production. Despite intestinal microbial populations and respective proportions were not determined in the chyme at this stage of the experiment, the finding of higher molar proportion of $n$-valeric acid in ABD appears to be suggestive. Interestingly, the increase in n-valeric acid content of caecum chyme in relationship with the other VFAs may be an indicator of the effect of fermentation selected upon the substrate. Probably, high native acorn starch (double if compared to control diet) found in the caecum or dietary polyphenols may have had an impact on the different VFA proportions found in pigs of the experimental diets. Higher $\mathrm{pH}$ values detected in caecum chyme of ABD pigs (despite non significantly different from $\mathrm{pH}$ values in caecum chyme of pigs fed with the control diet) can be interpreted in view of lesser extents of bacterial fermentations as mirrored by lower VFA content in this tract. However, in light of higher starch content in DM of digesta of the caecum from ABD pigs, higher VFA could have been reasonably expected. In reality, VFA content was significantly lower if compared to that determined in pigs fed with the control diet. Other authors reported that dietary tannic acid (TA) is capable to significantly reduce short chain fatty acids (SCFA) production in the hindgut at a dose of $2.5 \%$ on DM basis in the diet. The explanation to the effect observed was related to the capability of TA to retard the metabolic activities of microbial population and arguably of fermentations and respective end products [36]. The crude fiber content in the diet of the ABD pigs should not be misleading about results on VFA content in the caecum because the main fraction is represented by lignin due to acorns containing $102 \mathrm{~g}$ of sulfuric acid soluble-lignin $/ \mathrm{kg}$ DM [14].

\section{Conclusions}

The addition of acorns in the diet of growing pigs gave rise to different amounts of starch entering the caecum and VFA content in the caecum chyme compared to the diet without. The PCD of acorn starch was high (95\%) despite being lower than that observed in the complete diet based on barley and soybean meal (99.7\%). The high content of starch entering the ceacum following hulled shredded acorn consumption can potentially undergo bacterial fermentation and therefore be expected to act as a pre-biotic in association with TAE, pointing to different molar proportion of the investigated VFA (increased molar proportion of n-valeric acid).

Author Contributions: Conceptualization, methodology, software analysis, validation, investigation, data curation, writing — original draft preparation, writing—review and editing: M.G.C., P.W., P.R., W.P., and J.K.; supervision: J.K. All authors have read and agreed to the published version of the manuscript.

Funding: This research was carried out with internal funding.

Acknowledgments: Authors are thankful to the whole staff of the Institute of Nutrition Physiology and Animal Nutrition, University of Rostock, Germany.

Conflicts of Interest: The authors declare no conflict of interest. 


\section{References}

1. Joffre, R.; Rambal, S.; Ratte, J.P. The dehesa system in southern Spain and Portugal as a natural ecosystem mimic. Agrofor. Syst. 1999, 45, 57-79. [CrossRef]

2. Nieto, R.; Rivera, M.; Garca, M.A.; Aguilera, J.F. Amino acid availability and energy value of acorn in the Iberian pig. Livest. Sci. 2002, 77, 227-239. [CrossRef]

3. Pinna, W.; Nieddu, G.; Moniello, G.; Cappai, M.G. Vegetable and animal food sorts found in the gastric content of sardinian wild boars (Sus scrofa meridionalis). J. Anim. Physiol. Anim. Nutr. 2007, 91, 252-255. [CrossRef] [PubMed]

4. Cappai, M.G.; Wolf, P.; Liesner, V.G.; Kastner, A.; Nieddu, G.; Pinna, W.; Kamphues, J. Effect of whole acorns (Quercus pubescens) shred based diet on parotid gland in growing pigs in relation to tannins. Livest. Sci. 2010, 134, 183-186. [CrossRef]

5. Lopez-Bote, C.; Fructuoso, G.; Mateos, G.G. El cerdo iberico. Sistemas de procion porcina y calidad de la carne. Cerdo Iber FEDNA 2000, 16, 77-111.

6. Henkin, Z.; Gutman, M.; Aharon, H.; Perevolotsky, A.; Ungar, E.D.; Seligman, N.G. Suitability of Mediterranean oak woodland for beef herd husbandry. Agric. Ecosyst. Environ. 2005, 109, 155-161. [CrossRef]

7. Chiofalo, B.; Liotta, L.; Zumbo, A.; Chiofalo, L. Seasonal variation of free fatty acids in plasma of Nero Siciliano pigs living in extensive conditions. Vet. Res. Commun. 2013, 27, 253-255. [CrossRef]

8. Papanastasis, V.P.; Yiakoulaki, M.D.; Decandia, M.; Dini-Papanastasi, O. Integrating woody species into livestock feeding in the Mediterranean areas of Europe. Anim. Feed Sci. Technol. 2008, 140, 1-17. [CrossRef]

9. Rey, A.I.; Daza, A.; Lopez-Carrasco, C.; Lòpez-Bote, C.J. Feeding Iberian pigs with acorns and grass in either free-range of confinement affects the carcass characteristics ad fatty acids and tocopherols accumulation in Longissimus dorsi muscle and backfat. Meat Sci. 2005, 73, 66-74. [CrossRef]

10. Dasa, A.; Mateos, A.; Rey, A.I.; Ovejero, I.; Lòpez-Bote, C.J. Effect of duration of feeding under free-range condition on production results and carcass and fat quality in Iberian pigs. Meat Sci. 2007, 6, 411-461.

11. Tejerina, D.; García-Torres, S.; Cabeza de Vaca, M.; Vázquez, F.M.; Cava, R. Acorns (Quercus rotundifolia Lam.) and grass as natural sources of antioxidants and fatty acids in the "montanera" feeding of Iberian pig: Intraand inter-annual variations. Food Chem. 2011, 124, 997-1004. [CrossRef]

12. Holman, R.M.; Robbins, W.W. A Textbook of General Botany; Wiley and Sons, Inc.: New York, NY, USA, 1944.

13. Cappai, M.G.; Wolf, P.; Pinna, W.; Kamphues, J. Pigs use endogenous proline to cope with acorn (Quercus pubescens Willd.) combined diet high in hydrolysable tannins. Livest. Sci. 2013, 155, 316-322. [CrossRef]

14. Cappai, M.G.; Wolf, P.; Pinna, W.; Kamphues, J. The bilateral parotidomegaly (hypertrophy) induced by acorn consumption in pigs is dependent on individual's age but not on intake duration. Livest. Sci 2014, 167, 263-268. [CrossRef]

15. Cappai, M.G.; Wolf, P.; Rust, P.; Pinna, W.; Kamphues, J. Digestibility coefficient of crude nutrients in raw hulled acorns (Quercus pubescens Willd.) fed to growing pigs. Anim. Feed Sci. Technol. 2014, 197, 148-154. [CrossRef]

16. Cappai, M.G.; Alesso, G.A.; Nieddu, G.; Sanna, M.; Pinna, W. Electron microscopy and composition of raw acorn starch in relation to in vivo acorn starch digestibility. Food Funct. 2013, 4, 917-922. [CrossRef] [PubMed]

17. Rodriguez-Estevez, V.; Garcia Martinez, C.; Perea Munoz, J.M.; Gomez Castro, A.G. Measures and nutritional characteristics of Quercus acorns from the dehesa. Arch. Zootec. 2008, 57, 1-12.

18. Rezar, V.; Salobir, J.; Levart, A.; Tomažin, U.; Škrlep, M.; Batorek Lukač, N.; Čandek-Potokar, M. Supplementing entire male pig diet with hydrolyzable tannins: Effect on carcass traits, meat quality and oxidative stability. Meat Sci. 2017, 133, 95-102. [CrossRef]

19. Galassi, G.; Mason, F.; Rapetti, L.; Crovetto, G.M.; Spanghero, M. Digestibility and metabolic utilisation of diets containing chestnut tannins and their effects on growth and slaughter traits of heavy pigs. Ital. J. Anim. Sci. 2019, 18, 746-753. [CrossRef]

20. Aldritt, I.; Whitham-Agut, B.; Sipin, M.; Studholme, J.; Trentacoste, A.; Tripp, J.A.; Cappai, M.G.; Ditchfield, P.; Deviése, T.; Hedges, R.E.M.; et al. Metabolomics reveals diet-derived polyphenols accumulate in physiological bone. Sci. Rep. 2019, 9, 8047. [CrossRef] 
21. Morales, J.; Pérez, J.F.; Martín-Orúe, S.M.; Fondevila, M.; Gasa, J. Large bowel fermentation of maize or sorghum acorn diets fed as different source of carbohydrates to Landrace and Iberian pigs. Br. J. Nutr. 2002, 88, 489-497. [CrossRef]

22. Fondevila, M.; Morales, J.; Pérez, J.F.; Barrios-Urdaneta, A.; Baucells, M.D. Microbial caecal fermentation Iberic or Landrace pigs given acorn/sorghum or maize diets estimated in vitro by the gas production technique. Anim. Feed Sci. Technol. 2002, 102, 93-107. [CrossRef]

23. Mößeler, A.; Vagt, S.; Beyerbach, M.; Kamphues, J. Starch origin and thermal processing affect starch digestion in a minipig model of pancreatic exocrine insufficiency. Gastroenterol. Res. Pract. 2015, 872872. [CrossRef] [PubMed]

24. Directive 2010/63/EU of the European Parliament of and of the Council of 22 September 2010 on the Protection of Animals Used for Scientific Purposes. 2010. Available online: https://eur-lex.europa.eu/LexUriServ/ LexUriServ.do?uri=OJ:L:2010:276:0033:0079:en:PDF (accessed on 26 June 2020).

25. Willing, B.P.; Van Kassel, A.G. Enterocyte proliferation and apoptosis in the caudal small intestine is influenced by the composition of colonizing commensal bacteria in the neonatal gnotobiotic pig. J. Anim. Sci. 2007, 85, 3256-3266. [CrossRef]

26. Naumann, C.; Bassler, R. Die Chemische Untersuchung von Futtermitteln (Chemical Analyses of Animal Feed); VDLUFA-Verlag: Darmstadt, Germany, 2012.

27. Commission Directive 1999/79/EC of 27 July 1999 Amending the Third Commission Directive 72/199/EEC of 27 April 1972 Establishing Community Methods of Analysis for the Official Control of Feeding Stuffs. 1999. Available online: https://eur-lex.europa.eu/eli/dir/1999/79/oj (accessed on 26 June 2020).

28. Folin, O.; Ciocalteau, V. On tyrosine and tryptophane determination in proteins. J. Biol. Chem. 1927, 73, 424-427.

29. Waterman, P.G.; Mole, S. Analysis of plant metabolites. In Methods in Ecology Series; Waterman, P.G., Mole, S., Eds.; Blackwell Scientific Publications: Oxford, UK, 1994.

30. Ramana, D.B.V.; Vijay Kumar, A.; Sudheer, D.; Maini, S. Improvement in nutrient utilization in Deccani rams fed with coarse cereal crop residue as basal diet by polyherbal supplements. J. Vet. Sci. 2014, 115, 338-343.

31. Martin, L.J.M.; Dumon, H.J.W.; Champ, M.M.J. Production of short-chain fatty acids from resistant starch in a pig model. J. Sci. Food Agric. 1998, 77, 71-80. [CrossRef]

32. Canibe, N.; Bach Knudsen, K.E. Degradation and physicochemical changes of barley and pea fibre along the gastrointestinal tract of pigs. J. Sci. Food Agric. 2001, 82, 27-39. [CrossRef]

33. Bird, A.R.; Vuaran, M.; Brown, I.; Topping, D.L. Two high amylosemaize starches with different amounts of resistant starch vary in their effects on fermentation, tissue and digesta mass accretion, and bacterial populations in the large bowel of pigs. Br. J. Nutr. 2007, 97, 134-144. [CrossRef]

34. Hedemann, M.S.; Bach Knudsen, K.E. Resistant starch for weaning pigs-effect on concentration of short chain fatty acids in digesta and intestinal morphology. Livest. Sci. 2007, 108, 175-177. [CrossRef]

35. Cherbut, C.; Aubé, A.C.; Blottiére, H.M.; Galmiche, J.P. Effects of short chain fatty acids on gastrointestinal motility. Scan. J. Gastroenterol. Suppl. 1997, 222, 58-61. [CrossRef]

36. Bravo, L.; Abia, R.; Eastwood, M.A.; Saura-Calixtol, F. Degradation of polyphenols (catechin and tannic acid) in rat intestinal tract. Effect on colonic fermentation and faecal output. Br. J. Nutr. 1994, 71, 933-946. [CrossRef] [PubMed]

Publisher's Note: MDPI stays neutral with regard to jurisdictional claims in published maps and institutional affiliations.

(C) 2020 by the authors. Licensee MDPI, Basel, Switzerland. This article is an open access article distributed under the terms and conditions of the Creative Commons Attribution (CC BY) license (http://creativecommons.org/licenses/by/4.0/). 